\title{
Trends in goose numbers wintering in Britain \& Ireland, 1995 to 2008
}

\author{
Trender för antal gäss som övervintrar i Storbritannien och Irland 1995-2008 \\ CARL MITCHELL, KENDREW COLHOUN, ANTHONY D. FOX, LARRY GRIFFIN, \\ COLETTE HALL, RICHARD HEARN, CHAS HOLT \& ALYN WALSH.
}

\begin{abstract}
Twelve migratory and native goose populations winter in Britain and Ireland and up to date information on their abundance and distribution is provided. Seven populations are increasing: Barnacle Goose (Svalbard, current estimate 26,900 birds), Barnacle Goose (Greenland 70,500), Pink-footed Goose (288,800), North West Scotland Greylag Goose (34,500), Re-established Greylag Goose (50,000), Light-bellied Brent Goose (East Canadian High Arctic 34,000) and Light-bellied Brent Goose (Svalbard 3,270). Two populations appear stable: Taiga Bean Goose (432 at two sites) and Icelandic Greylag Goose $(98,300)$. Three populations are decreasing: European White-fronted Goose $(2,760)$ due to short stopping in mainland Europe, Dark-bellied Brent Goose $(82,970)$, due to a recent population decline (due to poor breeding success) and short stopping, and Greenland Whitefronted Goose $(24,055)$ due to recent poor breeding success and, up to 2006, hunting. An estimated 120,000 migratory geese wintered in Britain and Ireland in 1960 compared to 500,000 in 2008 . Despite many goose species demonstrating high degrees of site faithfulness (re-

sponding to safe roosts and regular food supply), shifts in winter distribution of several goose populations have occurred (notably Icelandic Greylag Goose).

Carl Mitchell, Colette Hall and Richard Hearn, Wildfowl \& Wetlands Trust (WWT), Slimbridge, Gloucester, GL2 7BT, UK.E-mail: carl.mitchell@wwt.org.uk. Kendrew Colhoun, Royal Society for the Protection of Birds (RSPB) Northern Ireland Office, Belvoir Park Forest, Belfast BT8 7QT, UK.

Anthony D. Fox, Department of Wildlife Ecology and Biodiversity, National Environmental Research Institute, Aarhus University, Kalø, Grenåvej 14, DK-8410 Rønde, Denmark.

Larry Griffin, WWT Caerlaverock, Dumfries \& Galloway, UK.

Chas Holt, British Trust for Ornithology (BTO), The Nunnery, Thetford, Norfolk, IP24 2PU, UK.

Alyn Walsh, National Parks and Wildlife Service, Wildfowl Reserve, North Slob, Wexford, Ireland.
\end{abstract}

\section{Introduction}

Of the eight species of geese (Anser and Branta) considered naturally occurring in the Western Palearctic region, 27 "populations" or "flyways" were defined in Madsen et al. (1999). Of these, 12 populations occur in Britain and Ireland. Canada Geese Branta canadensis were introduced in Britain from the 17 th century and, as a non-native species, are not considered in this review. Geese wintering in Britain and Ireland come from a wide breeding area including north west Canada, Greenland, Iceland, Svalbard, Fennoscandia and northern Russia. The breeding areas are vast and generally inaccessible and population assessments have traditionally taken place during the non-breeding season.

Information on goose abundance and distribu- tion is important for four primary reasons: (i) international legislation and conventions to which the UK is a signatory require such information as evidence that the state of biodiversity is being maintained; (ii) for supporting site-based conservation measures using the " $1 \%$ criterion" (see Madsen et al. 1999); (iii) many geese are quarry species and international legislation requires hunting to be sustainable; (iv) many goose populations have become reliant on agricultural land, especially during the non-breeding season, which brings them into conflict with farmers (see Fox et al., this volume). This assessment updates abundance data since the review by Madsen et al. (1999) for geese belonging to the 12 populations that winter in Britain and Ireland. 


\section{Methods}

We used traditional definitions of bio-geographical populations (after Madsen et al. 1999) and terminology (see also Table 1), defining units within species that share breeding, staging and wintering areas in a manner that is helpful for their conservation management. Britain and Ireland provide the winter quarters for almost all geese from six populations, c. $95 \%$ of two populations, $40-60 \%$ of two populations and c. $1 \%$ of two populations (Table 1).

Goose counting in Britain and Ireland is well organised at the national level (see Mitchell et al. 1997). Experienced observers either count roosting flocks coming to or from night time roosts or check daytime feeding areas. For some populations, complete annual coverage is too expensive, with surveys carried out at less frequent intervals. For example, Barnacle Geese (Greenland) Branta leucopsis winter on remote offshore islands in Ireland and Britain, necessitating aerial survey, which has been carried out at approximately five year intervals (Mitchell et al. 2009). For three populations, where no specific national surveys are carried out, geese are counted via the Wetland Bird Survey (WeBS). Since this fails to cover all of the populations, an indexing technique is applied to track relative changes in numbers from incomplete data (see Holt et al. 2009). For these populations, national totals are given (i.e. the number of birds counted from an incomplete survey). For each population, we present brief summary information on abundance and distribution up to 1995 (covered in detail in Madsen et al. 1999), a review of abundance and distribution from 1995 to 2008 and suggest possible causes of any recent changes.

\section{Data sources}

The data presented here originate from a range of different sources. Wherever possible, the data for a given population are collated by a responsible group which has co-ordinated regular counts following common protocols to generate population estimates in a reasonably comprehensive and consistent manner. The groups involved in the co-ordination, compilation and reporting of goose numbers are given in Table 1. The Wildfowl \& Wetlands Trust (WWT) produces an annual summary of the latest goose monitoring activities (GooseNews) and also publish this material online. This augments summary information collected by the WeBS scheme (e.g. Holt et al. 2009).

\section{Population trend data}

We assessed the rate of change in abundance by regressing the logarithmically transformed annual population estimate on year to give an annual (percentage) rate of change. We attempted to fit such models from 1960/1961 to 2008/2009 and from the last 14 years (1995/1996 to 2008/2009). Data sources for the abundance estimates are provided, along with the time series for which the analysis is available. Time periods of assessment refer either to a winter (e.g. 1995/1996) or year $(1995=$ winter 1995/1996). In line with current practice (e.g. Kershaw \& Cranswick 2003) we present the mean of the highest winter counts from the most recent five years as the estimate of the population size.

\section{Results}

Taiga Bean Goose Anser fabalis fabalis

The Bean Goose was regarded as a common winter visitor to northern Britain and East Anglia during the 19th century, and the commonest goose species in many localities in the former region (Berry 1939). Widespread declines began in the 1860 s, so by the early 20th century, only a few pockets remained (Owen et al. 1986). In the Yare Valley, Norfolk, a flock winters on undisturbed wet marshes and old, rough grazing meadows. Numbers declined from over c. 200 birds in the 1940 s to $50-60$ birds in the early 1960 s, followed by a slow increase to c. 200 in the late 1970 s and subsequently to over 400 birds (maximum 485 in 1990/1991). In Scotland, a regular flock of Bean Geese finally disappeared from the Dee Marshes, Galloway, in the early 1990s, where geese had been recorded from the late 1940s (maximum 240 in 1954/1955), whilst the numbers wintering on the Slamannan

\footnotetext{
${ }^{1}$ WeBS is a partnership of the British Trust for Ornithology (BTO), Royal Society for the Protection of Birds (RSPB) and the Joint Nature Conservation Committee (JNCC), in association with the Wildfowl \& Wetlands Trust (WWT).

${ }^{2}$ www.wwt.org.uk/research/monitoring
} 
Table 1. Approximate percent of goose population/flyway wintering in Britain and Ireland, terminology in this paper and in "Madsen" (Madsen et al. 1999), organisations/groups co-ordinating count data provided in this review and quarry status in Britain and Ireland.

Ungefärlig procentandel av gåspopulation som övervintrar i Storbritannien och Irland, organisation eller grupp som sammanställt de data som presenteras i denna uppsats samt populationens jaktbarhet $i$ Storbritannien och Irland. Quarry = jaktbar; Non-quarry = ej jaktbar. För artnamn se sammanfattningen.

\begin{tabular}{|c|c|c|c|c|}
\hline $\begin{array}{l}\text { Terminology } \\
\text { used in the text } \\
\text { Terminologi } i \\
\text { denna uppsats } \\
\end{array}$ & $\begin{array}{l}\text { Terminology } \\
\text { in "Madsen" } \\
\text { Terminologi } i \\
\text { "Madsen" }\end{array}$ & $\begin{array}{l}\text { Percent of } \\
\text { population } \\
\text { Procent av } \\
\text { beståndet }\end{array}$ & $\begin{array}{l}\text { Co-ordinating } \\
\text { organisation/group } \\
\text { Samordnande } \\
\text { organisation/grupp }\end{array}$ & $\begin{array}{l}\text { Quarry status } \\
\text { Jaktbarhet }\end{array}$ \\
\hline $\begin{array}{l}\text { Taiga Bean } \\
\text { Goose }\end{array}$ & $\begin{array}{l}\text { Taiga Bean } \\
\text { Goose }\end{array}$ & $<1 \%$ & $\begin{array}{l}\text { Bean Goose Action Group (BGAG) \& } \\
\text { RSPB }\end{array}$ & Non-quarry \\
\hline $\begin{array}{l}\text { Pink-footed } \\
\text { Goose }\end{array}$ & $\begin{array}{l}\text { Pink-footed } \\
\text { Goose: Iceland/ } \\
\text { Greenland }\end{array}$ & $\sim 100 \%$ & $\begin{array}{l}\text { WWT/Joint Nature Conservation } \\
\text { Committee (JNCC)/Iceland Institute } \\
\text { of Natural History (IINH) }\end{array}$ & Quarry \\
\hline $\begin{array}{l}\text { European White- } \\
\text { fronted Goose }\end{array}$ & $\begin{array}{l}\text { White-fronted } \\
\text { Goose }\end{array}$ & $<1 \%$ & WeBS Partnership & Quarry \\
\hline $\begin{array}{l}\text { Greenland White- } \\
\text { fronted Goose }\end{array}$ & $\begin{array}{l}\text { Greenland White- } \\
\text { fronted Goose }\end{array}$ & $\sim 100 \%$ & $\begin{array}{l}\text { Greenland White-fronted Goose } \\
\text { Study (GWGS) }\end{array}$ & Quarry $^{1}$ \\
\hline $\begin{array}{l}\text { Icelandic } \\
\text { Greylag Goose }\end{array}$ & $\begin{array}{l}\text { Greylag Goose: } \\
\text { Iceland }\end{array}$ & $\sim 95 \%$ & WWT/JNCC/IINH & Quarry \\
\hline $\begin{array}{l}\text { NW Scotland } \\
\text { Greylag Goose }\end{array}$ & $\begin{array}{l}\text { Greylag Goose: } \\
\text { Scotland }\end{array}$ & $100 \%$ & $\begin{array}{l}\text { WWT/Scottish Natural Heritage } \\
\text { (SNH) }\end{array}$ & Quarry \\
\hline $\begin{array}{l}\text { Re-established } \\
\text { Greylag Goose }\end{array}$ & $\begin{array}{l}\text { Greylag Goose: } \\
\text { Feral, UK }\end{array}$ & $100 \%$ & WeBS Partnership & Quarry \\
\hline $\begin{array}{l}\text { Barnacle Goose } \\
\text { (Greenland) }\end{array}$ & $\begin{array}{l}\text { Barnacle Goose: } \\
\text { Greenland }\end{array}$ & $100 \%$ & WWT/SNH & Non-quarry $^{2}$ \\
\hline $\begin{array}{l}\text { Barnacle Goose } \\
\text { (Svalbard) }\end{array}$ & $\begin{array}{l}\text { Barnacle Goose: } \\
\text { Svalbard }\end{array}$ & $100 \%$ & WWT/SNH & Non-quarry \\
\hline $\begin{array}{l}\text { Dark-bellied } \\
\text { Brent Goose }\end{array}$ & $\begin{array}{l}\text { Dark-bellied } \\
\text { Brent Goose }\end{array}$ & $\sim 40 \%$ & WeBS Partnership & Non-quarry \\
\hline $\begin{array}{l}\text { Light-bellied } \\
\text { Brent Goose } \\
\text { (East Canadian } \\
\text { High Arctic) } \\
\end{array}$ & $\begin{array}{l}\text { Light-bellied } \\
\text { Brent Goose: } \\
\text { Canada }\end{array}$ & $\sim 95 \%$ & $\begin{array}{l}\text { Irish Brent Goose Research Group } \\
\text { (IBGRG) }\end{array}$ & Non-quarry \\
\hline $\begin{array}{l}\text { Light-bellied } \\
\text { Brent Goose } \\
\text { (Svalbard) }\end{array}$ & $\begin{array}{l}\text { Light-bellied } \\
\text { Brent Goose: } \\
\text { Svalbard }\end{array}$ & $40-60 \%$ & Natural England/WeBS Partnership & Non-quarry \\
\hline
\end{tabular}

Plateau, Falkirk area increased since their discovery in the early 1980 s.

The distribution in the late 2000 s is restricted to these two regular wintering flocks, with sporadic occurrences elsewhere. In Norfolk, numbers have slowly declined to around 100-150 birds, possibly as a result of birds remaining on the continent to winter (short-stopping), whilst in Scotland, numbers have slowly increased to over 250 birds (maximum 300 in 2007/2008) although no interchange between the two sites is suspected. The result of the decline in the Norfolk flock and an increase in the Slamannan flock has been that the number wintering in Britain has stabilized at c. 400 birds, 
somewhat lower than the peak in the late 1980s and early 1990s (Figure 1a). Periods of hard weather on the continent may cause additional movements into Britain, often in late January and February; these can comprise A.f. fabalis and/or Tundra Bean Geese $A$. f. rossicus.

\section{Pink-footed Goose Anser brachyrynchus}

Confusion with the Bean Goose makes it difficult to assess how common the Iceland/Greenland Pinkfooted Goose population was in Scotland before the 20th century, although it is considered to have been a scarce winter visitor (Berry 1939). Regular autumn counts started in the early 1950s (systematic from winter 1960/1961). During the early autumn, c. $90 \%$ of the population can be counted on as few as 30 roost sites (Mitchell \& Hearn 2004). The censuses provide an accurate assessment of abundance (Frederiksen et al. 2004) and suggest that the population had increased from c. 60,000 birds in the early 1960 s to c. 225,000 in the mid 1990 s. The winter distribution is essentially the east and south of Scotland, north west and east England. Range contraction in the wintering quarters from the early $1950 \mathrm{~s}$ to the early 1970s (with increases in numbers in east central Scotland) was reversed from the late 1980s, with increasing numbers using agricultural land in Lancashire and, notably, sugar beet tops in north Norfolk (Gill et al. 1997). Resightings of individually marked birds have shown dispersal from Scotland into Lancashire and Norfolk, followed by late winter movements northwards through England and southern Scotland to important staging areas in east and north east Scotland and the Moray Firth (Fox et al. 1994).

Since the mid 1990s, numbers have continued to increase (maximum 351,188 in 2008/2009, Figure 1b). Despite an eight-fold increase in numbers, the early autumn distribution of Pink-footed Geese in Britain has largely remained congruent with earlier years (Figure 2a), with birds particularly loyal to roosts. As the population has increased, numbers at many individual roost sites have similarly increased, especially in the south of the winter range; sites in north and east Norfolk, for example, holding c. 152,500 birds in December 2004 and sites in south west Lancashire holding c. 90,000 birds in November 2008. However, a few roosts have seen dramatic decreases in use. Dupplin Loch, Perthshire, for example, held 62,000 birds in October 1994 (a quarter of the then population estimate), but the five year mean for 2004/2005 to 2008/2009 was only c.700 birds.

\section{European White-fronted Goose Anser albifrons} albifrons

The north west European population has grown substantially (Fox et al., this volume), but the number wintering in Britain has declined (Table 2). WWT counts since 1946/1947 show that the British total remained relatively stable through the 1950 s and early 1960 s (c. 8,000 geese) and increased to more than 10,000 between 1967 and 1970 (Figure1c). Thereafter, there was a decline, with temporary peaks (of up to c. 9,500) when severe weather forced more birds into Britain (e.g. 1978/1979). The principal resort was Slimbridge on the Severn Estuary, in south west England, which formerly held internationally significant numbers (Hearn 2004).

By the late 2000s, fewer than 3,000 birds were wintering in Britain (Figure 1c). Slimbridge, with an average of just 667 birds (2003/2004 to 2007/2008), remained an important British site, with about one quarter of the total wintering there. Among other important British sites are Heigham Holmes, Norfolk (c. 600 geese), the Swale Estuary, Kent (c. 400) and Holkham, Norfolk (c. 400); (see Holt et al. 2009). Only eight sites now support nationally important numbers ( $>58$ birds), compared to 13 sites in 1995/1996 (Figure 2b).

Trends at individual sites in recent decades have varied, particularly between sites in west and east Britain. Slimbridge is the only site in west Britain that still supports European White-fronted Geese; wintering flocks at all other sites (e.g. the Avon Valley, Hampshire) disappeared in the 1990s, or earlier. In contrast, sites in eastern Britain mostly show stable or increasing numbers, with several sites having only been consistently frequented since the 1990s (e.g. Heigham Holmes, Norfolk, North Warren, Suffolk, and Dungeness, Kent). This suggests that whilst western sites have been affected by the short stopping exhibited by this population, the 20 -fold population increase has resulted in a number of areas in eastern Britain supporting new, but small, flocks of geese, perhaps as sites in the Netherlands reach carrying capacity.

\section{Greenland White-fronted Goose Anser albifrons flavirostris}

Greenland White-fronted Geese migrate though south and west Iceland in the autumn to winter exclusively on the northern and western fringes of Britain and Ireland. The existing range reflects the natural distribution of ombrogenous bogs and wetlands which were its former traditional wintering 
a) Taiga Bean Goose

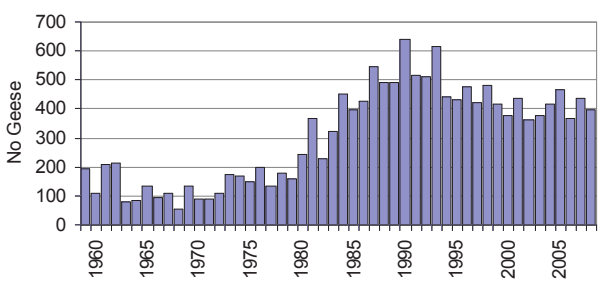

b) Pink-footed Goose

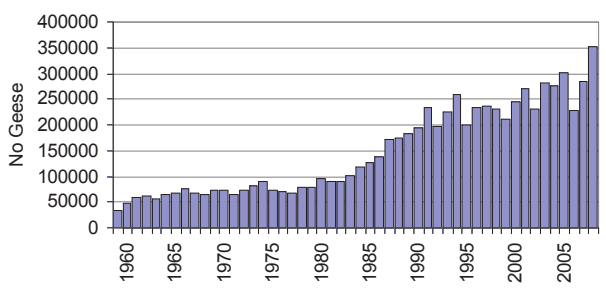

c) European White-fronted Goose

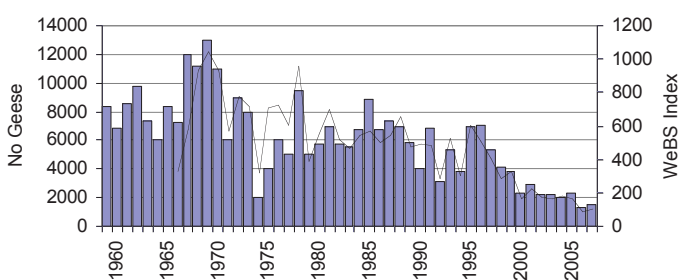

d) Greenland White-fronted Goose

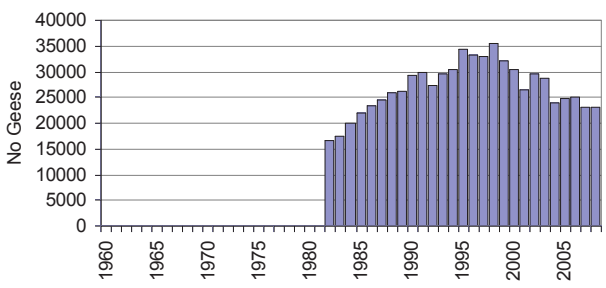

areas, although several flocks use farmland habitats which were colonised during the 1930s (e.g. some areas in Kintyre, south west Scotland). At the two most important wintering areas of Wexford (south east Ireland) and Islay (south west Scotland) the birds have increasingly used intensively managed grasslands, as elsewhere, although at some winter sites the species still favours landscapes charac- e) Icelandic Greylag Goose

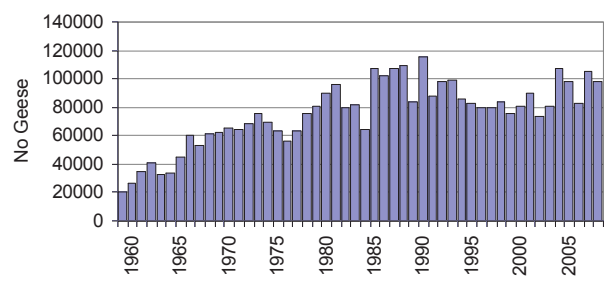

f) Re-established Greylag Goose

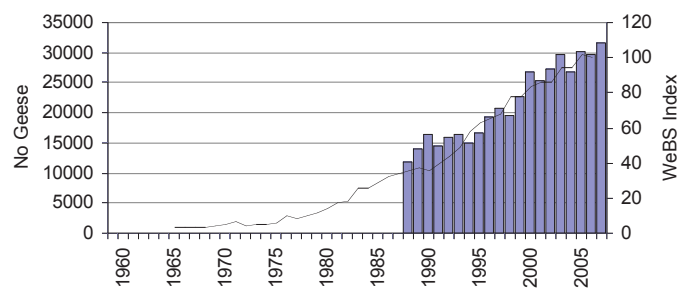

g) Barnacle Goose (Greenland)

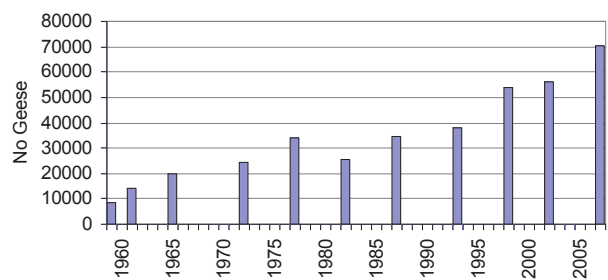

h) Barnacle Goose (Svalbard)

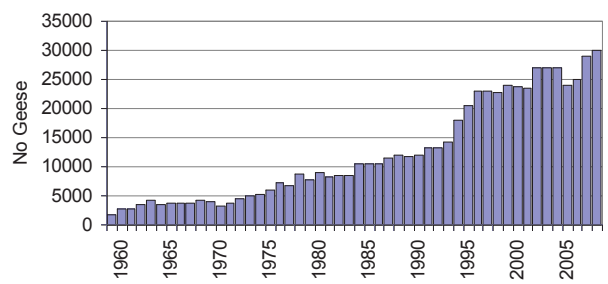

terised by peatlands and low intensity agriculture. Series of regular counts are available from Islay since 1965 and Wexford since 1968 as well as several other sites. Using counts and other information, Ruttledge \& Ogilvie (1979) suggested that the population of between 17,500 and 23,000 birds in the 1950 s had fallen to perhaps as few as 14,300 by the late 1970s. Monitoring of the whole popula- 
i) Dark-bellied Brent Goose

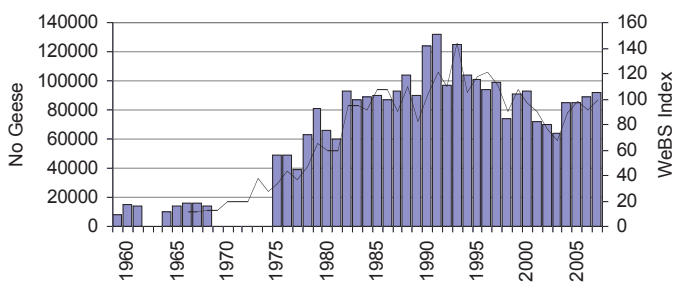

j) Light-bellied Brent Goose (East Canadian High Arctic)

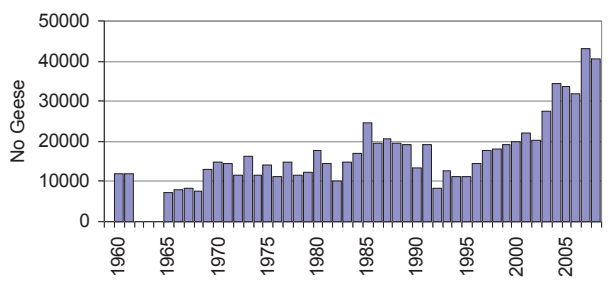

k) Light-bellied Brent Goose (Svalbard)

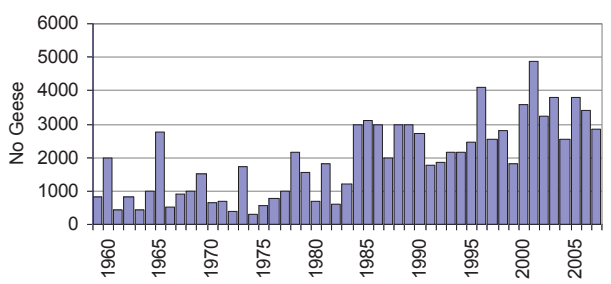

Figure 1. Maximum winter counts of geese in Britain and Ireland $1959 / 1960$ (1959) to 2008/2009 (2008). WeBS Index is shown for three populations, see text. See Table 2 for sources of count data.

Högsta antal gäss räknade $i$ Storbritannien och Irland 1959/1960 (1959) till 2008/2009 (2008). För tre populationer visas WeBS index, se texten. Se Tabell 2 för datakällor. För artnamn se sammanfattningen.

tion through a count network covering all known wintering sites began in 1982/1983, since when numbers increased from $16,000-17,000$ to 29,000 30,000 in 1993/1994, an annual increase of $5.2 \%$.

Numbers reached a peak of c. 35,600 birds in winter 1998/1999, but have decreased since then to an average of 24,055 (2004/2005 to $2008 / 2009$, Figure1d). Their present distribution has not changed since Ruttledge \& Ogilvie (1979) and Fox et al. (1998), and principally remains restricted to the north and west of Scotland and the west and north midlands of Ireland, with the notable exception of Wexford Slobs (Figure 2b). Since the review of Fox et al. (1998), five formerly regularly occupied sites in Scotland and nine in Ireland have become abandoned, adding to the contraction of range caused by former extinctions documented in Ruttledge \& Ogilvie (1979) and Fox et al. (1998).

\section{Icelandic Greylag Goose Anser anser}

Wintering Greylag Geese were uncommon in east and south Scotland throughout the 19th century (Berry 1939), but had become more numerous at several sites by the 1930s. This was followed by a period of steady increase in the middle of the 20th century, especially so in the 1950s. Regular autumn counts started in the early 1950s and suggest that the population increased from c. 36,000 birds in the early 1960 s to c. 110,000 individuals in the late 1980 s. However, in the early 1990 s, numbers declined and c. 86,000 were counted in 1994/1995. A northward contraction of the range began as long ago as the 1900s (Berry 1939) and continues to the present day. From the 1960s to the 1980s, the importance of north and east Scotland increased considerably, with a number of autumn roosts (e.g. Dinnet Lochs, Loch Eye, Loch of Skene) supporting both greater numbers and a greater proportion of the total population. In Ireland, c. 6,000 birds, of Icelandic origin, were thought to winter in 1949, mainly at the Wexford Slobs. Subsequently, the population declined in the 1950s and 1960s to c. 700 birds in 1967 before increasing again. By January 1995, an all-Ireland count of c. 4,700 wintering Icelandic Greylag Geese was reported (Boland \& Crowe 2008).

Since the mid 1990s, overall numbers continued to decrease reaching a low of c. 73,100 birds in 2002/2003, but since then have increased again, averaging c. 98,300 during 2004/2005-2008/2009 (Figurele). The northward range shift continued and, since the mid 1990s, increasing numbers have wintered on Orkney; by 2008/2009, c. 60,000 Greylag Geese were counted on the islands amounting to over half of the total winter population (Figure 2c). In winter $2007 / 2008$, c. 1,500 Greylag Geese were recorded in southern Iceland, the first time Greylag Geese had been recorded over-wintering there (A. Sigfusson, pers. comm., Mitchell 2009). In Ireland, numbers remained similar at c. 4,0006,000 birds in the early 2000 s, although there is thought to have been a recent decline, with only c. 2,200 recorded in 2008/2009. 
Figure 2.

a) Pink-footed Geese

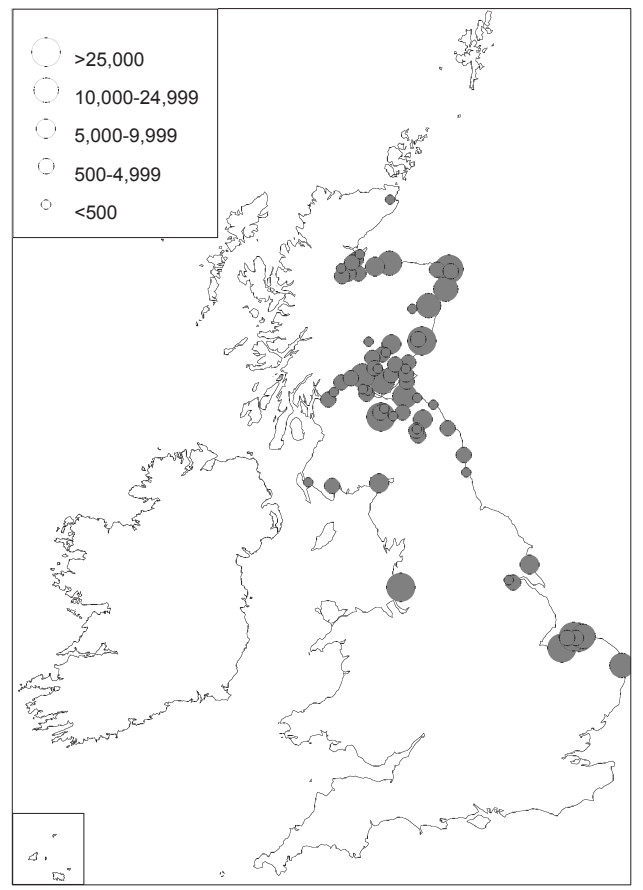

c) Icelandic Greylag Goose

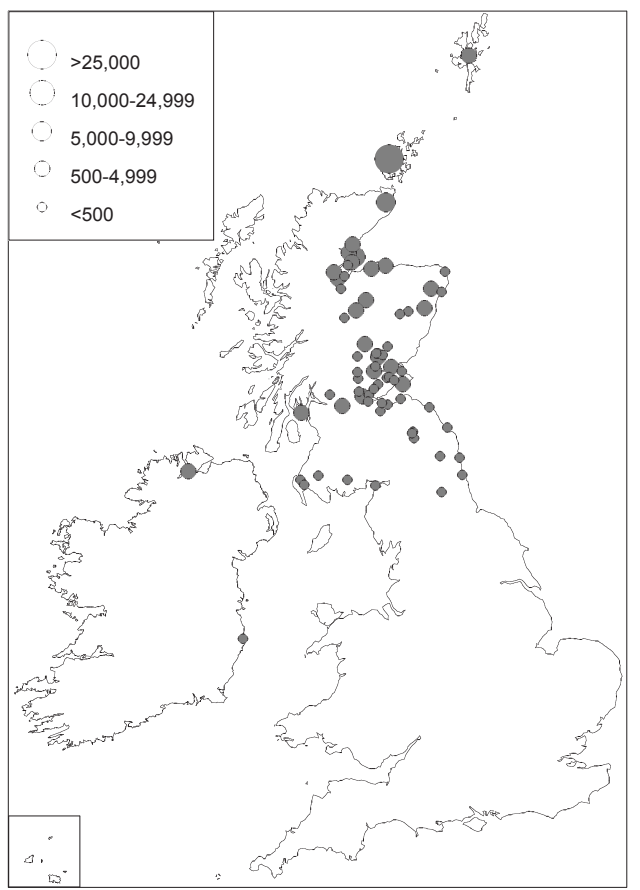

b) White-fronted Geese

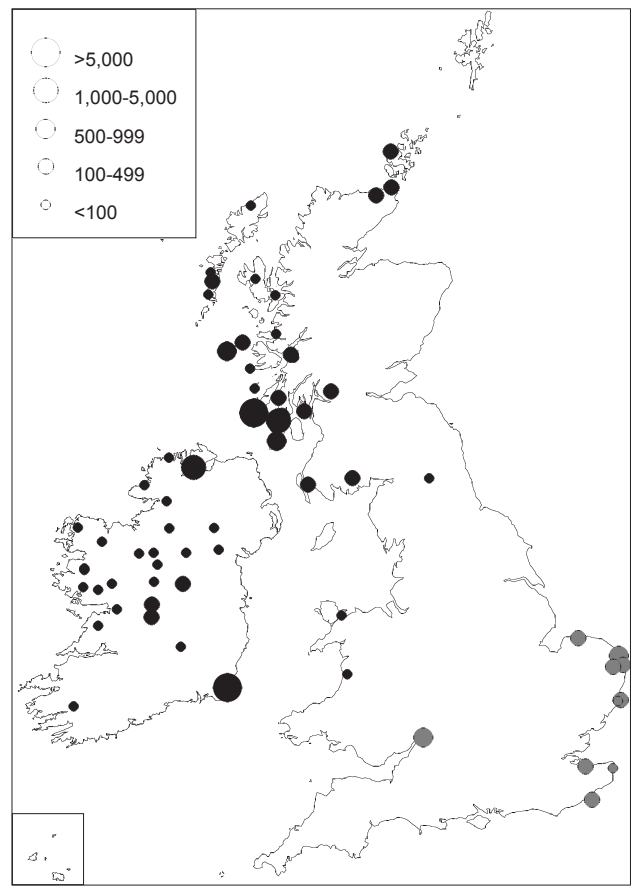

d) North west Scotland/Re-established Greylag Geese

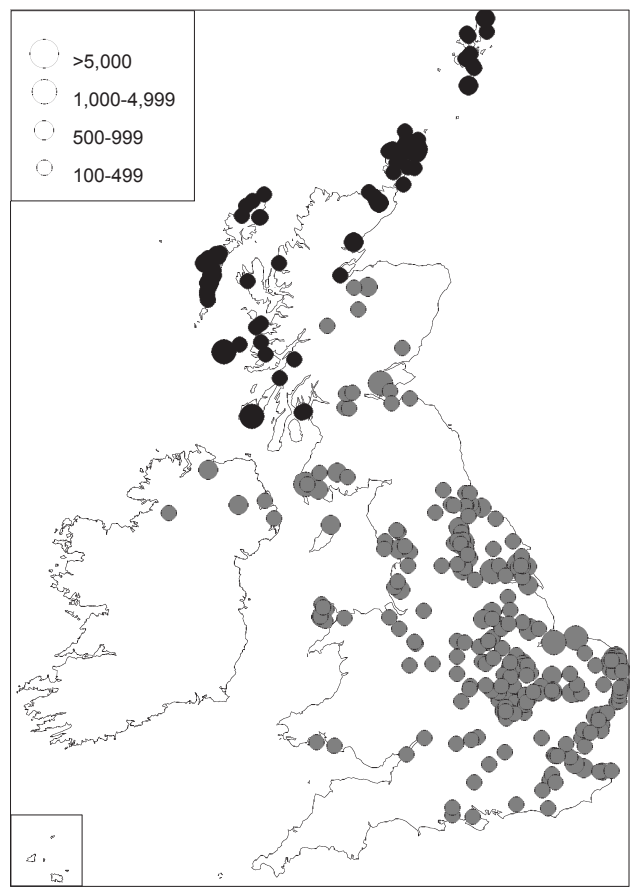


e) Barnacle Geese

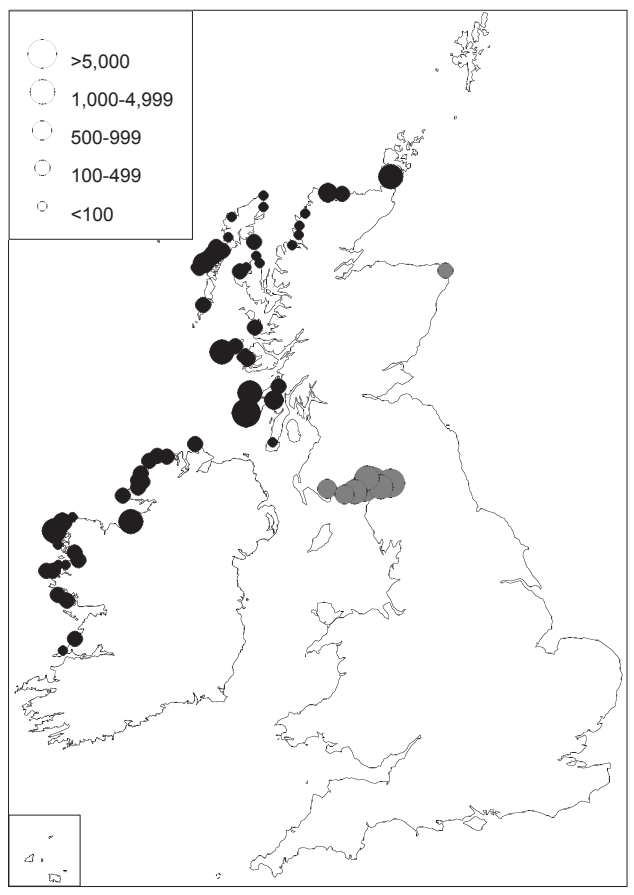

f) Brent Geese

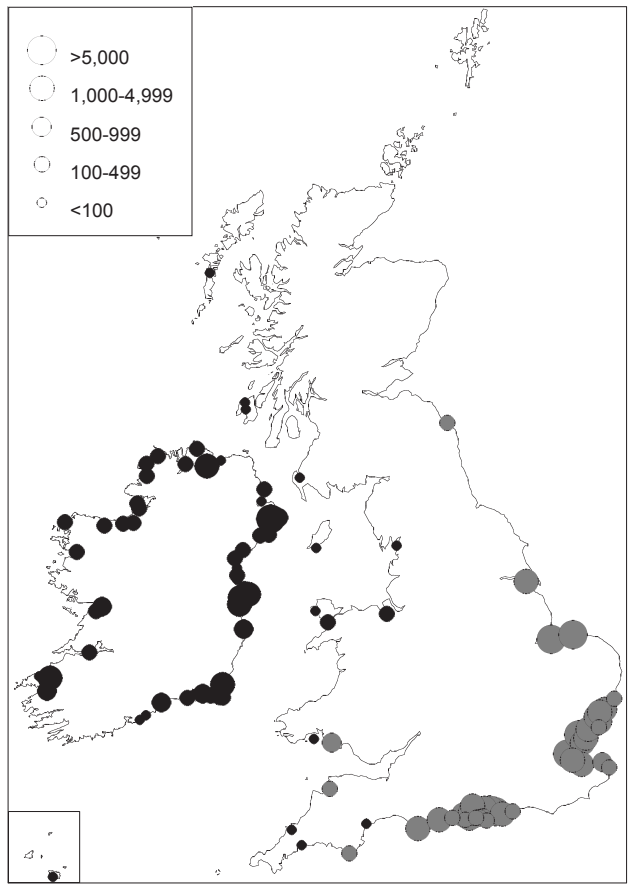

Figure 2. Distribution of geese in Britain and Ireland based on five year mean peak counts 2003/2004-2007/2008 (unless ofherwise indicated): (a) Pink-footed Geese, (b) White-fronted Geese; Greenland White-fronted Geese (black symbols) based on counts in spring 2009 and European White-fronted Geese (grey symbols), (c) Icelandic Greylag Goose, (d) North west Scotland/Re-established Greylag Geese; North west Scotland native birds (black symbols)/Re-established Greylag Geese in Scotland (grey symbols) based on counts in summer 2008 and 2009 and Re-established Greylag Geese in England, Wales and Ireland (grey symbols), (e) Barnacle Geese; Greenland Barnacle Geese (black symbols) based on counts made in March 2008 and Svalbard Barnacle Geese (grey symbols), (f) Brent Geese; Light-bellied Brent Goose (East Canadian High Arctic, black symbols) based on counts in 2007/2008-2008/2009 and Dark-bellied Brent Geese (grey symbols); Light-bellied Brent Geese (Svalbard) primarily winter at Kindisfarne and are not shown.

Gässens utbredning $i$ Storbritannien och Irland: (a) spetsbergsgås; medelvärden för högsta antal 2003/2004-2007/2008, (b) bläsgås: grönländska (svarta symboler, räknade våren 2009) och europeiska (grå symboler, medelvärden för högsta antal 2003/2004-2007/2008), (c) isländsk grågås, medelvärden för högsta antal 2003/2004-2007/2008, (d) övriga grågäss: nv. Skottlands ursprungliga (svarta symboler) och återetablerade grågäss i Skottland (grå symboler) enligt räkningar somrarna 2008 och 2009 samt återetablerade grågäss $i$ England, Wales och Irland (grå symboler) enligt medelvärden för högsta antal 2003/2004-2007/2008), (e) vitkindade gäss: från Grönland (svarta symboler) enligt räkningar i mars 2008 och från Svalbard (grå symboler) enligt medelvärden för högsta antal 2003/2004-2007/2008, (f) prutgäss: ljusbukade från högarktis $i$ östra Kanada (svarta symboler) enligt räkningar 2007/2008-2008/2009 och mörkbukade (grå symboler) enligt medelvärden för högsta antal 2003/2004-2007/2008. 
Table 2. Population estimates (mean winter peak and maximum count 2004/2005-2008/2009), data sources and trends for geese wintering in Britain and Ireland. For six populations, the number of birds wintering in Britain and Ireland form only a part of the flyway total - see Table 1 .

Beståndsuppskattningar (medelvärde för högsta vinterantal samt högsta antal någon vinter med året då detta inträffade) för gäss som övervintrar I Storbritannien och Irland. För sex bestånd utgör de fåglar som övervintrar $i$ Storbritannien och Irland endast en del - se Tabell 1. I de högra kolumnerna anges långtidstrend och korttidstrend med perioden för trenden. För artnamn se sammanfattningen.

\begin{tabular}{|c|c|c|c|c|c|c|}
\hline Population & $\begin{array}{l}\text { Present } \\
\text { Senaste }\end{array}$ & $\begin{array}{l}\text { Maximum } \\
\text { year } \stackrel{a}{r}\end{array}$ & $\begin{array}{l}\text { Coverage } \\
\text { Täckning }\end{array}$ & $\begin{array}{l}\text { Source } \\
\text { Källa }\end{array}$ & $\begin{array}{l}\text { Long term } \\
\text { trend }\end{array}$ & $\begin{array}{l}\text { Short term } \\
\text { trend }\end{array}$ \\
\hline $\begin{array}{l}\text { Taiga Bean } \\
\text { Goose }\end{array}$ & 432 & $\begin{array}{l}471 \\
2008 / 9\end{array}$ & $\begin{array}{l}\text { Annual, } \\
\text { complete }\end{array}$ & BGAG, RSPB, WWT ${ }^{5}$ & $\begin{array}{l}+3.8 \% \\
1960-2008\end{array}$ & $\begin{array}{l}-0.1 \% \\
1995-2008 \\
\end{array}$ \\
\hline $\begin{array}{l}\text { Pink-footed } \\
\text { Goose }\end{array}$ & 288,800 & $\begin{array}{l}351,200 \\
2008 / 9\end{array}$ & $\begin{array}{l}\text { Annual, } \\
\text { complete }\end{array}$ & Mitchell (2009) & $\begin{array}{l}+4.0 \% \\
1960-2008\end{array}$ & $\begin{array}{l}+2.8 \% \\
1995-2008 \\
\end{array}$ \\
\hline $\begin{array}{l}\text { European White- } \\
\text { fronted Goose }\end{array}$ & $2,760^{1,2}$ & $\begin{array}{l}2,350^{1} \\
2005 / 6\end{array}$ & $\begin{array}{l}\text { Annual, } \\
\text { trend }\end{array}$ & Holt et al. (2009) & $\begin{array}{l}-2.9 \% \\
1960-2007\end{array}$ & $\begin{array}{l}-13.2 \% \\
1995-2007\end{array}$ \\
\hline $\begin{array}{l}\text { Greenland White- } \\
\text { fronted Goose }\end{array}$ & 24,055 & $\begin{array}{l}25,168 \\
2006 / 7\end{array}$ & $\begin{array}{l}\text { Annual, } \\
\text { complete }\end{array}$ & Fox et al. (2009) & $\begin{array}{l}+1.1 \% \\
1983-2007\end{array}$ & $\begin{array}{l}-3.0 \% \\
1999-2007 \\
\end{array}$ \\
\hline $\begin{array}{l}\text { Icelandic } \\
\text { Greylag Goose }\end{array}$ & 98,300 & $\begin{array}{l}107,200 \\
2004 / 5 \\
\end{array}$ & $\begin{array}{l}\text { Annual, } \\
\text { complete }\end{array}$ & Mitchell (2009) & $\begin{array}{l}+1.8 \% \\
1960-2008\end{array}$ & $\begin{array}{l}+1.8 \% \\
1995-2008 \\
\end{array}$ \\
\hline $\begin{array}{l}\text { NW Scotland } \\
\text { Greylag Goose }\end{array}$ & $34,500^{3}$ & $\begin{array}{l}34,500^{3} \\
2008 / 9 \\
\end{array}$ & $\begin{array}{l}9 \text { years, } \\
\text { complete }\end{array}$ & Mitchell et al. (2010) & $\mathrm{n} / \mathrm{a}$ & $\mathrm{n} / \mathrm{a}$ \\
\hline $\begin{array}{l}\text { Re-established } \\
\text { Greylag Goose }\end{array}$ & $50,000^{4}$ & $50,000^{4}$ & $\begin{array}{l}\text { Annual, } \\
\text { trend }\end{array}$ & $\begin{array}{l}\text { Mitchell et al. (2010); } \\
\text { Holt et al. (2009) }\end{array}$ & $\mathrm{n} / \mathrm{a}$ & $\begin{array}{l}+4.9 \% \\
1995-2007\end{array}$ \\
\hline $\begin{array}{l}\text { Barnacle Goose } \\
\text { (Greenland) }\end{array}$ & 70,500 & $\begin{array}{l}70,500 \\
2007 / 8\end{array}$ & $\begin{array}{l}5 \text { years, } \\
\text { complete }\end{array}$ & $\begin{array}{l}\text { Mitchell et al. (2009); } \\
\text { Walsh \& Crowe (2008) }\end{array}$ & $\begin{array}{l}+3.1 \% \\
1961-2007\end{array}$ & $\begin{array}{l}+3.0 \% \\
1998-2007\end{array}$ \\
\hline $\begin{array}{l}\text { Barnacle Goose } \\
\text { (Svalbard) }\end{array}$ & 26,900 & $\begin{array}{l}29,900 \\
2008 / 9 \\
\end{array}$ & $\begin{array}{l}\text { Annual, } \\
\text { complete }\end{array}$ & WWT $^{5}$ & $\begin{array}{l}+5.3 \% \\
1960-2008\end{array}$ & $\begin{array}{l}+2.1 \% \\
1995-2008 \\
\end{array}$ \\
\hline $\begin{array}{l}\text { Dark-bellied } \\
\text { Brent Goose }\end{array}$ & $82,970^{1,2}$ & $\begin{array}{l}91,604^{1} \\
2007 / 8 \\
\end{array}$ & $\begin{array}{l}\text { Annual, } \\
\text { trend }\end{array}$ & Holt et al. (2009) & $\begin{array}{l}+4.3 \% \\
1960-2007\end{array}$ & $\begin{array}{l}-1.1 \% \\
1995-2007 \\
\end{array}$ \\
\hline $\begin{array}{l}\text { Light-bellied } \\
\text { Brent Goose } \\
\text { (East Canadian } \\
\text { High Arctic) } \\
\end{array}$ & 34,000 & $\begin{array}{l}39,000 \\
2007 / 8\end{array}$ & $\begin{array}{l}\text { Annual, } \\
\text { complete }\end{array}$ & $\begin{array}{l}\text { Kendrew Colhoun pers. } \\
\text { comm. }\end{array}$ & $\begin{array}{l}+2.4 \% \\
1960-2008\end{array}$ & $\begin{array}{l}+8.9 \% \\
1995-2008\end{array}$ \\
\hline $\begin{array}{l}\text { Light-bellied } \\
\text { Brent Goose } \\
\text { (Svalbard) }\end{array}$ & 3,270 & $\begin{array}{l}3,756 \\
2005 / 6\end{array}$ & $\begin{array}{l}\text { Annual, } \\
\text { complete }\end{array}$ & Holt et al. (2009) & $\begin{array}{l}+3.9 \% \\
1960-2007\end{array}$ & $\begin{array}{l}+1.4 \% \\
1995-2007\end{array}$ \\
\hline
\end{tabular}

${ }^{1}$ Based on count data from 2003/04-2007/08. Räkningar från 2003/04-2007/08.

${ }^{2}$ National totals. These do not represent population estimates, since WeBS does not cover the entire population.

Nationella totalräkningar som inte är beståndsuppskattningar eftersom WeBS inte täcker hela beståndet.

${ }^{3}$ Based on survey carried out in Scotland in summer 2008 and 2009. Räkningar utförda i Skottland sommartid 2008 och 2009.

${ }^{4}$ Estimated; See text for calculation of Re-established Greylag Goose population estimate. Uppskattat; se texten för beräkning av den återetablerade grågåspopulationens storlek.

${ }^{5}$ www.wwt.org.uk/research/monitoring

North west Scotland Greylag Goose Anser anser The Greylag is the only species of goose breeding in a native state in Britain and Ireland and formerly had a widespread but localised distribution. During the 19th century numbers began to decline, likely linked to the drainage and cultivation of the fens and excessive hunting, causing local extinction of the species. By the 1870 s, Greylag Geese remained only in the Outer Hebrides with very small numbers in west mainland Scotland. The north west Scotland (or native) Greylag Goose population, as it became known, was thus the remnant of 
the population formerly widespread over Britain, numbering less than 500 birds by the 1930s, their lowest numbers in historic times (Berry 1939). The numbers and distribution slowly increased, such that by the late $1980 \mathrm{~s}, \mathrm{c} .1,500$ were reported from Tiree \& Coll, c. 1,580 from the Uists and c. 2,500 in Sutherland (Mitchell et al. 2000).

The first co-ordinated census found c. 10,000 birds within the then known range of the population in 1997 (Mitchell et al. 2000). Greylag Geese first bred on Orkney and Shetland in the mid 1980s (although the provenance of the breeding birds in Shetland is unknown) and breeding numbers on both island groups have increased markedly since (Mitchell et al. 2010). Numbers of re-established Greylag Geese breeding in Scotland were also increasing (see below) and, by the early 2000 s, separation of the two populations was based merely on historical geographic boundaries (Figure 2d). By $2008 / 2009$, a second survey found c. 34,500 (range 33,370 to 36,200 ) Greylag Geese in the historical range of the north west Scotland Greylag Goose population (Mitchell et al. 2010), an increase of $245 \%$ since the 1997 census.

\section{Re-established Greylag Goose Anser anser}

Greylag Geese were re-established in Britain from the 1930s, mainly released by wildfowlers in areas of former occurrence. The majority were derived from within the North west Scotland Greylag Goose population range (see above) but it is possible that very small numbers of Iceland-bred geese, taken in winter, were also involved and it is known that a very small number of A.a.rubirostris were introduced into Kent. From the late 1950s, wildfowling organisations released Greylag Geese from existing re-established flocks in ten more counties in England and Wales and in smaller numbers in Scotland. Despite the disappearance of native habitat (natural fens, bogs and marshes) from much of Britain, although less so in Scotland, Greylag Geese adapted to modified or artificial habitats for both breeding and wintering. Owen \& Salmon (1988) estimated there to be 13,000 to 14,000 re-established Greylag Geese in Britain in $1985 / 1986$ and that numbers were increasing at $\mathrm{c}$. $13 \%$ per annum.

By 2000, numbers were estimated at c. 24,500, increasing at c. $9.4 \%$ per annum (Austin et al. 2007). Trends within Britain are calculated using counts of birds during winter from the Wetland Bird Survey since the species is widespread and normally winters close to the breeding areas (Figure1f). The distribution of breeding Greylag Geese in the late 2000s now covers much of lowland Britain (Figure 2d). Using the estimated rate of increase in England and Wales (Austin et al. 2007) and an estimated c. 12,900 (range 10,690 to 15,550 ) geese in Scotland based on a separate survey in 2008/2009, it was estimated that the total number in Britain was likely to be c. 50,000 (Mitchell et al. 2010). With birds from the north west Scotland and reestablished populations increasing and forming a near continuous range within Britain and Ireland, it is perhaps timely to consider these as belonging to a single population.

\section{Barnacle Goose (Greenland) Branta leucopsis}

The Greenland population of Barnacle Geese winters almost exclusively in north and west Scotland and west Ireland (Figure 2e). In Scotland, the wintering range extends throughout the Inner and Outer Hebrides and north to Orkney. In western Ireland, the main concentrations occur between the Dingle Peninsula, Co. Kerry, and Inishowen in north Co. Donegal. There have been 12 full international censuses since the first complete survey of wintering sites in 1959/1960, conducted at approximately five-yearly intervals, mostly in late March/early April (e.g. Mitchell et al. 2009, Walsh \& Crowe 2009). Some wintering sites can be covered by ground counts, but the inaccessible nature of many sites (some are uninhabited, comparatively remote islands) requires aerial survey to achieve complete coverage. Annual ground counts at several accessible key sites in Scotland and Ireland occur (e.g. Islay, Tiree \& Coll, South Walls (Orkney) and Inishkea Islands (Mayo, west Ireland)). Annual ground counts on Islay started in 1952/1953 because Islay holds a particularly high (and increasing) percentage of the total population. In 1959, Islay held one third of the total population, but by 2008 , this had increased to $64 \%$

The total population has increased more than eight-fold since the first full census in 1959; reaching c. 56,400 in March 2003 and c. 70,500 in March 2008 (Figure 1g). There have been only modest changes in winter distribution in Scotland in recent years. Some islands have ceased to hold winter flocks, usually associated with land use change, notably cessation of summer grazing. In Ireland, the distribution has also remained more or less unchanged, although the most southerly haunts have been abandoned (e.g. the Blasket Islands, the Wexford Slobs and Lurgangreen, Louth).

Barnacle Goose (Svalbard) Branta leucopsis In the early parts of the 20th century, the Svalbard 
Barnacle Goose was said to be a common bird on the Solway Firth, it not being uncommon to see flocks of 6,000 geese. However, by the 1930s a drastic decline had already occurred. In the mid1940s, there was considerable disturbance from wartime activities and heavy shooting; the lowest ever count of 300 was in 1948. The geese were protected from shooting in Britain in 1954 and in Svalbard in 1955 and this, with the establishment of the National Nature Reserve (NNR) at Caerlaverock in 1957 , led to a recovery in numbers to $3,000-4,000$ birds in the 1960s. Further increases, to 13,000 14,000 birds in the early 1990 s, followed the establishment of the WWT reserve at Caerlaverock in 1970 and the declaration of breeding sanctuaries on the main island sites in Svalbard in 1973.

The population had been predicted to level off at c. 12,000 birds based on the assumption that as the population grew the absolute number of young produced would not increase (Owen \& Norderhaug 1977). However, numbers continued to steadily increase, with 29,900 counted in 2008/2009 (Figure $1 \mathrm{~h}$ ). The geese have a localised distribution in the non-breeding season, although the geese now make considerable use of the saltmarshes on the Cumbrian side of the Solway Firth from Anthorn to Skinburness Marsh and have extended their range westwards as far as Wigtown in Scotland. Even so, the breadth of the winter range from east to west is still only $50 \mathrm{~km}$ (Figure 2e). In addition, small numbers, generally less than 100 birds, occasionally over winter at Loch of Strathbeg, Aberdeenshire. The use of inland fields is still far less frequent on the south side of the Solway than in the north. The geese traditionally used the saltmarsh habitats of the Solway, moving to adjacent agricultural land within $5 \mathrm{~km}$ of the coast after arrival, utilising stubbles heavily in the autumn. The geese roost on sand- and mudflats adjacent to areas of saltmarsh. Three areas have been used extensively for feeding; the Caerlaverock area including fields and saltmarsh along the River Nith, Rockcliffe Marsh, and farmland around Southerness/Mersehead.

\section{Dark-bellied Brent Goose Branta bernicla bernicla}

Until the 1930s, the Dark-bellied Brent Goose was common along western European coasts, particularly associated with the vast eelgrass Zostera spp. beds which then existed. Following a wasting disease which decimated this food plant in the 1930s, flyway numbers declined from several hundred thousand to less than 20,000 birds. The first reliable population estimate was of 16,500 birds in the mid 1950s with approximately half of these in southern Britain (Salomonsen 1958). Numbers increased slowly until 1972, after which the total population reached c. 327,900 in 1991. Between 40 and $60 \%$ of the flyway population winters in Britain, depending partly on prevalent weather conditions in Britain and on the continent (Mitchell et al. 1994). Numbers in Britain increased from 40,000 to 60,000 birds in the late 1970 s, in line with the increase of the overall population. Wintering sites are primarily distributed along the south east and south coasts of England, with eelgrass beds at Maplin Sands, off Foulness Island, and at Leigh-on-Sea key autumn staging areas. Ring re-sightings have revealed that considerable numbers of birds passing through this area move on to winter in France, while others move north to winter on Norfolk and Essex estuaries and west along the south coast of England (Ebbinge \& St. Joseph 1992). As the population increased up to the 1990s, the distribution within Britain expanded, notably near to existing important sites on the Wash, Suffolk and Essex coasts but also west to south Wales and north as far as the Humber Estuary and Lindisfarne (Figure 2f).

Since the mid 1990s, the flyway population declined by about one-third to just under 200,000 birds (in 2003/2004), partly as a result of low breeding success, but then increased again to c. 250,000 in $2008 / 2009$. The proportion wintering in Britain followed a similar pattern, declining to c. 64,400 in $2003 / 2004$, but recovering to c. 91,600 in $2007 / 2008$ (Figure 1i). However, the proportion of the global population wintering in Britain has declined from c. $50 \%$ in the $1950 / 1960$ s to c. 30 $40 \%$ in the late $2000 \mathrm{~s}$, suggesting that some birds are short-stopping on the continent. In winters $2003 / 2004$ to $2007 / 2008$, the most important sites were the Wash (c. 21,400 geese), the Thames Estuary (c. 13,000) and Chichester Harbour (c. 9,300) (Holt et al. 2009).

\section{Light-bellied Brent Goose (East Canadian High Arctic) Branta bernicla hrota}

The size of the East Canadian High Arctic Lightbellied Brent Goose population was largely unknown before the 1950s. The first complete Irish census found c. 11,900 birds in 1960/1961. Counts during the 1960 s varied between c. 7,300 $(1965 / 1966)$ and c. $11,000-16,000$ in the 1970 s. There was a marked increase to over 24,500 birds in autumn 1985 followed by an apparent decline to as few as 8,300 geese in the early 1990s (survey coverage in the early and mid 1990s was relatively poor). Strangford Lough in Northern Ireland hosts 
over $75 \%$ of the entire population during the late autumn and is by far the most important site for staging geese in the early autumn. Lough Foyle, on the north coast, acts as an increasingly important site for autumn arrivals as does the Tralee Bay/ Castlemaine Harbour complex in the south west. As winter progresses, birds disperse around the coast of Ireland with notably high numbers at Dublin Bay and Wexford Harbour and Slobs (Figure 2f). Much smaller flocks also occur along the west coast of Britain, e.g. the flock established at Loch Ryan, Galloway, in the Channel Islands, north France (Normandy) and north west Spain (Robinson et al. 2004).

Numbers increased through the mid to late 1990s peaking at 39,000 in winter 2007/2008 (Figure 1j). This increase has resulted in higher mid-winter counts at many sites around Ireland, the establishment of flocks at previously unoccupied sites and is likely to be a driver for increased feeding on agricultural and amenity grasslands. Higher numbers in western Britain have occurred in recent years and the flocks in north France currently peak at 1,000-1,500 birds. Counts undertaken for the WeBS and Irish Wetland Bird Survey (I-WeBS) indicate that 25 sites in Ireland are internationally important for this population, regularly supporting at least 200 individuals.

\section{Light-bellied Brent Goose (Svalbard) Branta bernicla hrota}

The East Atlantic population of Light-bellied Brent Goose breeds on Svalbard, Franz Joseph Land and in north east Greenland. In late August to late September, they migrate down the west Norwegian coast to winter in Denmark and at Lindisfarne in north east England. In severe winters, when Danish waters become frozen, some birds also disperse to winter in the Netherlands. The population suffered a severe decline in size during the 1930s, at the time of the wasting disease affecting eelgrass beds, perhaps exacerbated by local hunting and egg collecting on Svalbard. This population may have been as large as $40,000-50,000$ birds prior to the decline (Salomonsen 1958), with an estimated 20,000 birds thought to belong to this population wintering on the Moray Firth, north Scotland, in the early years of the 20th century (Owen et al. 1986). By the late 1940s and early 1950s, however, the whole population was estimated at c. 4,000 birds (Salomonsen 1958), declining to $1,600-2,000$ birds in the late $1960 \mathrm{~s}$, the majority of which wintered in Denmark. Since 1980, annual co-ordinated counts have been made at the sites used by the geese in late autumn/mid-winter, and in Britain have shown a slow but steady increase from c. 1,500 birds in the early 1980 s to c. 3,300 by the late 2000 s. The only site regularly used in Britain since the 1960s is Lindisfarne (but see below).

Since the mid 1990s, Lindisfarne has been used by up to $50-70 \%$ of the entire population, despite a reduction in the frequency of cold winters. Numbers wintering there have largely increased in line with the population as a whole (estimated at c. 7,000 in 2008/2009), reaching over 4,000 birds in 1996/1997 and 2001/2002 (Figure 1k). Small groups are regularly seen along the east coast of Scotland and north England for brief periods, especially in the early autumn. These birds are thought to be on their way to Lindisfarne. Since the 1990s, however, two small winter flocks (generally less than 50 birds) have become established in Scotland; one at Nairn on the Moray Firth and another at the Eden Estuary (Mitchell \& Ogilvie 2007).

\section{Discussion}

In the 1930s there was considerable concern over the number of geese in northern Europe with many populations at very low numbers due primarily to over-hunting. In Britain, successive conservation measures introduced after the Second World War (e.g. 1954 Protection of Birds Act, protection from hunting for certain populations, the introduction of nature reserves, the re-establishment of breeding Greylag Geese, the ban on the sale of goose carcasses, the 1981 Wildlife \& Countryside Act) and changes in agricultural practices, some of which benefited grazing geese, led to an increase in numbers in many wild goose populations. In 1960, it was estimated that there were c. 120,000 migratory geese wintering in Britain and Ireland (AtkinsonWilles 1963). By 2008, that number had increased to half a million geese (Table 2).

For Pink-footed Geese, the key drivers for the sustained increase in abundance are considered to be the site safeguard of important winter roosts (from the 1980s), improved winter feeding conditions (notably in Norfolk), a relatively high mean breeding success rate of c. 20\% (1950-2008) and a decline in overall mortality (Fox et al. 1989, Mitchell \& Hearn 2004). As the population has increased, hunting mortality has not increased at the same rate, thus the proportion shot each year has declined. Autumn hunting of Pink-footed Geese in Iceland is relatively modest, compared to Greylag Geese, since the former are found in the more remote interior. Similar factors have operated on the 
three Greylag Goose populations (Fox et al. 1989, Frederiksen et al. 2004, Hearn \& Mitchell 2004). For the Icelandic Greylag Goose population, the decline to c. 73,000 in the late 1990 s/early 2000 s, was probably a result of an annual bag harvest of c. 25,000-40,000 birds in Iceland (Frederiksen et al. 2004) in addition to an estimated harvest of c. 20,000-25,000 in Britain (Frederiksen 2002). The increase and then stabilisation of numbers since the early 2000s (Figure 1e) may have partly been a result of the shift in distribution north to Orkney. It appears that this has resulted in a reduced annual harvest in Britain that has allowed numbers to recover (Trinder 2009, Mitchell 2009). For both the re-established and north west Scotland populations, a reduction in mortality (through limited hunting opportunities) and an average long term breeding success of over $20 \%$ means both populations have been able to re-occupy areas of former occurrence leading to rapid increases in abundance and distribution.

For Dark-bellied Brent Geese, European Whitefronted Geese and possibly Taiga Bean Geese (in Norfolk) declines in the wintering populations in Britain are partly attributable to short-stopping, where geese winter closer to their breeding areas following an improvement in feeding conditions there and possibly winter conditions in north west continental Europe becoming less severe (Owen et al. 1986). The proportion of these global populations now wintering in Britain is lower than 30-40 years ago. In addition, for the Dark-bellied Brent Geese, lower breeding success since the 1980s has affected the overall population level.

Consistently low reproductive success since 1995 in Greenland White-fronted Geese, perhaps linked to weather conditions on the breeding areas (Boyd \& Fox 2008) and/or competition with Canada Geese on the breeding grounds has failed to replace annual losses in the population which has been the demographic cause of decline in the overall population size since 1999 . However, prior to 2006 , up to c. 3,400 birds were also being shot annually in Iceland, although hunting of this population has now been stopped.

Under the EC Birds Directive, Barnacle Geese have been protected in Europe since 1981 and, as annual recruitment has generally exceeded mortality, numbers have increased. Large parts of the winter quarters in Scotland are farmland close to Special Protection Areas (SPAs) and farmers are paid to maintain feeding opportunities for the geese with little or no disturbance. However, the Scottish Government allows 'lethal scaring' as part of a goose payment scheme in Islay. It is estimated that up to c. 1,000 birds are shot there annually, and together with a further c. 3,000 shot annually in Iceland, this may yet reduce the rate of increase of the Greenland population. As both populations have increased, reproductive success has declined, which may also reduce the rate of increase.

Whilst the numbers of different geese have changed markedly in the last 80 years, there have been shifts in the distribution of some species too. Many goose flocks re-appear in familiar places year after year, demonstrating a high degree of site faithfulness. The geese are responding to a safe roost and regular food supply. Other flocks have shifted, some markedly. More Pink-footed Geese, in terms of numbers and the proportion of the population, are migrating to more southerly winter quarters in Lancashire and Norfolk, where the geese take advantage of waste sugar beet cuttings without causing agricultural conflict (see Gill et al. 1997). Conversely, the majority of Icelandic Greylag Geese have moved from wintering quarters in east and central Scotland to winter on Orkney, some c. $500 \mathrm{~km}$ closer to Iceland. Short-stopping along the migration route, to remain closer to the breeding grounds, has individual life history advantages with the first birds to arrive back on the breeding grounds often having better breeding success (e.g. Dalhaug et al. 1996). Likewise, despite the overall flyway population levels increasing in Dark-bellied Brent Geese and European White-fronted Geese, fewer birds now winter in Britain, the birds making shorter autumn migrations and staying to winter in Germany, the Netherlands, Poland and Denmark.

The East Canadian High Arctic population of Light-bellied Brent has been increasing steadily since the mid-1990s. This increase has been recorded during the near-synchronous autumn counts throughout the flyway but is also apparent in the increases of bird numbers at all established wintering haunts and the establishment of new wintering sites. The pattern may be related to a sustained period of above average productivity, perhaps related to improved conditions on the breeding grounds. The Svalbard population of Light-bellied Brent Goose is one of only two goose populations in the Western Palearctic numbering less than 10,000 birds (Fox et al., this volume), and Britain regularly hosts c. $50-70 \%$ of the entire population. Whilst the population is slowly increasing, there has been a recent decline in annual reproductive success which makes future population growth uncertain.

For most populations, the quality of the abun- 
dance estimates for the UK and Ireland is considered to be high because of the effort put into coordinated coverage of known sites, the systematic and consistent coverage achieved, and the accessibility and documentation relating to the compilation of the count data. However, despite the organisation and collation of count data being part funded by governments, much of the monitoring is undertaken by a volunteer network and, faced with possible changes in economic circumstances, the continuation of this level of monitoring is fragile. For three populations (Dark-bellied Brent Goose, European White-fronted Goose and Re-established Greylag Goose) trends in abundance are monitored through an indexing scheme (as part of WeBS) and whilst trend data are considered accurate, national count totals often fall short of a total population estimate (see Holt et al. 2009). This is perhaps less of a problem for the Dark-bellied Brent Goose and European White-fronted Goose where a large proportion of the winter population is monitored through WeBS coverage, but for the Re-established Greylag Goose, with a relatively dispersed population, count totals could be substantially lower than the actual population size.

Large scale ringing initiatives are not currently being undertaken for any goose population in Britain or Ireland (although small scale schemes do exist for Barnacle Geese (both populations) and Greenland White-fronted Geese). In addition, unlike in some European countries, systematic bag data are not collected in Britain and Ireland. These knowledge gaps have major implications for assessing current population dynamics, in particular future Population Viability Analyses (PVAs), and possible future population levels, and thus European Union and other internationally agreed obligations to assess the sustainability of the management of these populations.

\section{Acknowledgements}

Goose counting in Britain and Ireland is largely dependent on thousands of volunteer counters and local co-ordinators. Our thanks are expressed to them all for the understanding they have given us of these populations. Most goose counts in Britain are supported either through the Wildfowl \& Wetlands Trust / Joint Nature Conservation Committee Goose \& Swan Monitoring Programme, through Scottish Natural Heritage initiatives, such as Local Goose Management Schemes, or through the Wetland Bird Survey (a partnership between BTO, RSPB and JNCC, in association with WWT).
In Ireland, goose monitoring is supported by the Northern Ireland Environment Agency, the National Parks \& Wildlife Service and BirdWatch Ireland.

\section{References}

Atkinson-Willes, G. 1963. Wildfowl in Great Britain. HMSO, London.

Austin, G.E., Rehfisch, M.M., Allan, J.R. \& Holloway, S.J. 2007. Population size and differential population growth of introduced Canada Geese Branta canadensis and reestablished Greylag Geese Anser anser across habitats in Great Britain in the year 2000. Bird Study 54: 343-352.

Berry, J. 1939. The status and distribution of wild geese and wild duck in Scotland. International Wildfowl Inquiry, Vol II. The University Press, Cambridge.

Boland, H. \& Crowe, O. 2008. An assessment of the distribution and range of Greylag (Icelandic-breeding and feral populations) in Ireland. Report to the National Parks and Wildlife Service and the Northern Ireland Environment Agency. BirdWatch Ireland, Newtown Mountkennedy.

Boyd, H. \& Fox, A.D. 2008. Effects of climate change on the breeding success of White-fronted Geese Anser albifrons flavirostris in West Greenland. Wildfowl 53: 55-70.

Dalhaug, L., Tombre, I.M. \& Erikstad, K.E. 1996. Seasonal decline in clutch size of the Barnacle Goose in Svalbard. The Condor 98: 42-47.

Ebbinge, B.S. \& St. Joseph, A.K.M. 1992. The Brent Goose colour-ringing scheme: unravelling annual migratory movements from high arctic Siberia to the coasts of western Europe. Pp. 93-104 in Ebbinge, B.S. Population limitation in arctic-breeding geese. Published PhD thesis, University of Groningen.

Fox, A.D., Gitay, H., Owen, M., Salmon, D.G. \& Ogilvie, M.A. 1989. Population dynamics of Icelandic-nesting geese. Ornis Scandinavica 20: 289-297.

Fox, A.D., Mitchell, C., Stewart, A., Fletcher, J.D., Turner, J.V.N., Boyd, H., Shimmings, P., Salmon, D.G., Haines, W.G. \& Tomlinson, C. 1994. Winter movements and sitefidelity of Pink-footed Geese Anser brachyrhynchus ringed in Britain, with particular emphasis on those marked in Lancashire. Bird Study 41: 221-234.

Fox, A.D., Norriss, D.W., Stroud, D.A., Wilson, H.J. \& Merne, O.J. 1998. The Greenland White-fronted Goose in Ireland and Britain 1982/83-1994/95: Population change under conservation legislation. Wildlife Biology 4: 1-12.

Fox, A.D., Francis, I.S. \& Walsh, A. 2009. Report of the 2008/2009 International census of Greenland Whitefronted Geese. National Parks \& Wildlife Service, Dublin and Greenland White-fronted Goose Study, Aberystwyth.

Fox, A.D., Ebbinge, B.S., Mitchell, C., Heinicke, T., Aarvak, T., Colhoun, K., Clausen, P., Dereliev, S., Farago, S., Koffijberg, K., Kruckenberg, H., Loonen, M., Madsen, J., Mooij, J., Musil, P., Nilsson, L., Pihl, S. \& Van der Jeugd, H. 2010. Current estimates of goose population sizes in the western Palearctic, a gap analysis and an assessment of trends. Ornis Svecica 20: 115-127.

Frederiksen, M. 2002. Indirect estimation of the number of migratory Greylag and Pink-footed Geese shot in Britain. Wildfowl 53: 27-34.

Frederiksen, M., Hearn, R.D., Mitchell, C., Sigfússon, A.P., Swann, R.L. \& Fox, A.D. 2004. The size and dynamics 
of Icelandic-breeding goose populations: a reassessment of the evidence. Journal of Applied Ecology 41: 315-334.

Gill, J.A. Watkinson, A.R. \& Sutherland, W.A. 1997. Causes of redistribution of Pink-footed Geese Anser brachyrhynchus in Britain. Ibis 139: 497-503.

Hearn, R.D. 2004. Greater White-fronted Goose Anser albifrons albifrons (Baltic/North Sea population) in Britain 1960/61-1999/2000. Waterbird Review Series. WWT/ JNCC, Slimbridge.

Hearn, R.D. \& Mitchell, C. 2004. Greylag Goose Anser anser (Iceland population) in Britain 1960/61-1999/2000. Waterbird Review Series. WWT/JNCC, Slimbridge.

Holt, C.A., Austin, G.E., Calbrade, N.A., Mellan, H., Thewlis, R.M., Hall, C., Stroud, D.A., Wotton, S.R. \& Musgrove, A.J. 2009. Waterbirds in the UK 2007/08: The Wetland Bird Survey. BTO/WWT/RSPB/JNCC, Thetford.

Kershaw, M. \& Cranswick, P.A. 2003. Numbers of wintering waterbirds in Great Britain, 1994/95-1998/99: I Wildfowl \& selected waterbirds. Biological Conservation 111: 91-104.

Madsen, J., Cracknell, G. \& Fox, A.D. (eds) 1999. Goose populations of the Western Palearctic. A review of status and distribution. Wetlands International. Publ. No. 48, Wetlands International, Wageningen, The Netherlands. National Environmental Research Institute, Rönde, Denmark.

Mitchell, C. 2009. Status and distribution of Icelandic-breeding geese: results of the 2008 international census. Wildfowl \& Wetlands Trust Report, Slimbridge.

Mitchell, C., Kirby, J.S., Salmon, D.G., \& Cranswick, P.A. 1994. Monitoring Dark-bellied Brent Geese Branta b. bernicla in Britain 1988-1994. Pp 179-188 in van Nugteren, J. (Ed) Proc. Int. Workshop Brent Geese in the Wadden Sea. Leeuwarden, The Netherlands, 22-23 Sept 1994.

Mitchell, C., Boyd, H., Owen, M. \& Ogilvie, M. 1997. Fifty years of goose research and conservation by WWT. Wildfowl 45: 231-240.

Mitchell, C., Patterson, D., Boyer, P., Cunningham, P., McDonald, R., Meek, E., Okill, J.D. \& Symonds, F. 2000. The summer status and distribution of Greylag Geese in north and west Scotland. Scottish Birds 21: 69-77.

Mitchell, C. \& Hearn, R.D. 2004. Pink-footed Goose Anser brachyrhynchus (Greenland/Iceland population) in Britain 1960/61-1999/2000. Waterbird Review Series. WWT/JNCC, Slimbridge.

Mitchell, C. \& Ogilvie, M.A. 2007. Brent Goose. In: Forrester, R., Andrews, I.J. et al. (Eds) The Birds of Scotland. The Scottish Ornithologists' Club, Aberlady.

Mitchell, C., Hall, C. \& Douse, A. 2009. Greenland Barnacle Geese in Scotland in 2008. Scottish Birds 29(2): 99-110.

Mitchell, C., Griffin, L., Trinder, M. \& Newth, J. 2010. The population size of breeding Greylag Geese Anser anser in Scotland in 2008/09. Report to Scottish Natural Heritage. WWT, Slimbridge.

Owen, M. \& Norderhaug, M. 1977. Population dynamics of Barnacle Geese Branta leucopsis breeding in Svalbard, 1948-1976. Ornis Scandinavica 8: 161-174.

Owen, M., Atkinson-Willes, G.L. \& Salmon, D.G. 1986. Wildfowl in Great Britain. $2^{\text {nd }}$ Edition, University Press, Cambridge.

Owen, M. \& Salmon, D.G. 1988. Feral Greylag Geese Anser anser in Britain \& Ireland, 1960-86. Bird Study 35: $37-45$.

Robinson, J.A., Colhoun, K., Gudmundsson, G., Boert- mann, D., Merne, O., O’Briain, M., Portig, A., Mackie, K. \& Boyd, H. 2004. Light-bellied Brent Goose Branta bernicla hrota (East Canadian High Arctic population) in Canada, Ireland, Iceland, France, Greenland, Scotland, Wales, England, the Channel Islands and Spain 1960/611999/2000. Waterbird Review Series. WWT/JNCC, Slimbridge.

Ruttledge, R.F. \& Ogilvie, M.A. 1979. The past and current status of the Greenland White-fronted Goose in Ireland and Britain. Irish Birds 1: 293-363.

Salomonsen, F. 1958. The present status of the Brent Goose (Branta bernicla (L.)) in western Europe. IWRB Publication 4.

Trinder, M. 2009. Status and population viability of Icelandic Greylag Geese in Scotland. Report to SNH. RPS, Glasgow.

Walsh, A. \& Crowe, O. 2008. Barnacle Geese Branta leucopsis in Ireland, spring 2008. Irish Birds 8: 430-432.

\section{Sammanfattning}

De åtta arter av gäss inom släktena Anser och Branta, som förekommer naturligt i västra Paläarktis har delats in i 27 separata populationer eller flyttvägar. Av dessa förekommer tolv populationer i Storbritannien och Irland, och i denna uppsats ger vi en uppdaterad sammanställning av utbredning, antal och förändringar. Den inplanterade kanadagåsen behandlas inte. Storbritannien och Irland utgör övervintringsområde för nästan alla gäss från sex av populationerna, ca $95 \%$ från två populationer, $40-60 \%$ från två populationer och ca $1 \%$ från två populationer (Tabell 1).

Gåsräkningarna är väl organiserade med ett stort antal kunniga och tränade observatörer som räknar gäss antingen när de lämnar eller anländer till sovplatsen eller när de betar under dagtid. Flera populationer totalräknas årligen. Vitkindade gäss, som övervintrar på avlägsna öar, räknas dock bara med flyg vart femte år. Och tre populationer saknar heltäckning, men indexeras med hjälp av stickprov inom Wetland Bird Survey. Informationskällorna framgår av Tabell 1.

Resultaten presenteras med högsta antal varje vinter som diagram i Figur 1. Trender (långtidsoch korttidstrender) anges i form av årlig procentuell förändring, vilken beräknats med regression av de logaritmerade antalsvärdena mot året (Tabell 2). I denna tabell ges också senaste beståndsskattning i form av femårsmedelvärdet för 2004/20052008/2009 samt det maximala antal som räknats under samma period. Gässens utbredning illustreras med kartor i Figur 2.

Taigasädgåsen (Figur 1a) var allmän på 1800-talet men minskade till två smärre flockar i slutet av 1900-talet. Dagens förekomst begränsar sig till 
dessa två flockar, 100-150 fåglar i Norfolk och 250-300 i Skottland.

Spetsbergsgåsen (Figur 1b och Figur 2a) ökade i antal från 60.000 på 1960 -talet till 225.000 på 1990-talet. Ökningen har fortsatt under 2000-talet och som mest har 350.000 fåglar räknats 2008/2009.

Den europeiska populationen av bläsgås (Figur 1c) har minskat fortlöpande från över 10.000 vissa år på 1970-talet till färre än 2000 de senaste vintrarna. De övervintrar i södra Storbritannien (Figur 2b).

Bläsgässen som kommer från Grönland via Island övervintrar främst på Irland och i västra Skottland (Figur 2b). Från de första räkningarna ökade antalet övervintrare till ett maximum på 35.600 fåglar 1998/1999 för att sedan sjunka till omkring 24.000 fåglar vid de senaste räkningarna.

Isländska grågäss övervintrar främst $\mathrm{i}$ östra Skottland (Figur 2c). Deras antal ökade stadigt från 1960-talet till 1980-talet men har sedan dess varierat mellan 70.000 och 100.000 fåglar (Figur 1e). Vintern 2007/2008 stannade 1500 gäss över vintern på Island, vilket är första gången.

Grågåsen är den enda naturligt häckande gåsen på de brittiska öarna och hade förr en vidare utbredning. I slutet av 1800-talet fanns dock bara en liten population kvar, bl.a. på Yttre Hebriderna. I dag är beståndet mera spritt över Skottland (Figur 2d) och har med bidrag från återetablering genom utsläpp ökat från som lägst 500 fåglar på 1930-talet till över 10.000 på 1990-talet. Sedan dess har grågåsbeståndet ökat ytterligare inom det ursprungliga området men det är inte längre möjligt att skilja individer från det ursprungliga beståndet från sådana som kommer från utsläppta gäss. I övriga Storbritannien återetablerades grågåsen nästan uteslutande genom utsläpp av jägare och den har fått vidsträckt spridning (Figur 2d). Beståndet uppgår i dag till över 30.000 efter en årlig ökningstakt på 9,4\% (Figur 1f). Med det skotska beståndet torde det i dag finnas omkring 50.000 grågäss som både häckar och övervintrar i Storbritannien och Irland.

De vitkindade gässen från Grönland övervintrar nästan uteslutande i norra och västra Skottland och västra Irland (Figur 2e) och deras antal har ökat stadigt till numera omkring 70.000 individer (Figur $1 \mathrm{~g})$.

Vitkindade gäss från Svalbard var 1948 nere i en så liten vinterpopulation som 300 fåglar. De fredades i Storbritannien 1954 och på Svalbard 1955 och har sedan ökat på ett enastående sätt till 30.000 fåglar vid den senaste räkningen (Figur 1h). Övervintringsområdet är mycket litet och har en största bredd på bara 50 kilometer (Figur 2e).
Den mörkbukiga rasen av prutgås (som kommer från norra Eurasien) övervintrar i sydöstra England (Figur 2f) och ökade starkt från 1960-talet till ett maximum under 1990-talets första år för att sedan gå tillbaka till en nivå runt 80.000 de senaste räkningarna (Figur 1i).

Den del av den ljusbukiga rasen av prutgäss som kommer från högarktiska Kanada och övervintrar på Irland (Figur 2f) har ökat, men egentligen först under 2000-talet (Figur 1j), och uppgår nu till ungefär 40.000 fåglar.

De ljusbukiga prutgäss som kommer från Svalbard, Franz Josefs land och nordöstra Grönland via Norges kust har bara en övervintringsplats på de brittiska öarna, nämligen i Lindisfarne och antalet uppgår numera till runt 7000 (Figur 1k).

Med alla arter inräknade har det övervintrande gåsbeståndet ökat från 120.000 fåglar 1960 till 500.000 fåglar 2008. Denna utveckling beror på en rad faktorer, något olika för olika populationer. Till en del beror det på att Storbritannien fått del i de allmänna beståndsökningar som skett inom flera gåspopulationer. För detta har minskad jakt, reservatsbildning och förbättrad födotillgång spelat stor roll. För en del populationer är förändringarna bara lokala för de brittiska öarna genom att övervintringsvanorna förändrats. Således har nedgången för prutgås och den europeiska populationen av bläsgås orsakats av att fåglarna stannar redan på kontinenten och till mindre del når de brittiska öarna. För prutgåsen kan sjunkande ungproduktion dessutom ha påverkat den totala populationen. Den grönländska bläsgåspopulationen har länge uppvisat för låg reproduktion, vilket är huvudorsaken till många års nedgång, men sedan 1996 är jakten förbjuden under passagen på Island.

Många gåsflockar är trogna sina övervintringsplatser från år till år, men en del förändringar har också skett. Förkortad flyttning har redan nämnts, och det har noterats hos ytterligare några populationer. Merparten av de isländska grågässen övervintrar numera på Orkneyöarna som ligger $500 \mathrm{~km}$ närmare Island än deras tidigare vinterområden. Många spetsbergsgäss har däremot förlängt flyttningen söderut för att kalasa på rester från de stora sockerbetsodlingarna i Lancashire och Norfolk.

Det finns i dag inga större märkprojekt för någon gåspopulation i Storbritannien eller Irland. Inte heller insamlas någon systematisk statistik över antal gäss som fälls vid jakt. Dessa kända brister minskar vår förmåga att studera populationsdynamiken, särkilt möjligheten att genomföra sårbarhetsanalyser, förutsäga framtida beståndsutveckling och utvärdera effekten av skydd och skötselåtgärder. 